\author{
Anna Markowicz • Gabriela Woźniak \\ Stawomir Borymski - Zofia Piotrowska-Seget \\ Damian Chmura
}

\title{
Links in the functional diversity between soil microorganisms and plant communities during natural succession in coal mine spoil heaps
}

Received: 10 December 2014 / Accepted: 12 August 2015/Published online: 1 September 2015

(C) The Author(s) 2015. This article is published with open access at Springerlink.com

\begin{abstract}
The successful establishment of vegetation, soil development and biogeochemical cycling during the restoration process of mine tailings requires a diverse and metabolically active microbial communities. The objective of this study was to test whether there is any link between the functional groups of both the dominant plant species and soil microbial communities on unreclaimed coal mine spoil heaps of different age located in the Silesian Upland (Poland). At each sampling site the dominant plant species were recorded and characterised based on their Raunkiaer's life form, socio-ecological group and their potential to form mycorrhiza. The functional diversity of the plantassociated microbial communities was assessed using the microbial carbon-utilisation guilds generated using the Biolog method. We observed no differences in the microbial functional diversity, but a gradual increase in the plant functional diversity with the age of the heap. Our results indicate that trees, plants with the potential to form ectomycorrhiza, and deciduous plants strongly affected
\end{abstract}

Electronic supplementary material The online version of this article (doi:10.1007/s11284-015-1301-3) contains supplementary material, which is available to authorized users.

A. Markowicz $(\bowtie) \cdot$ S. Borymski $\cdot$ Z. Piotrowska-Seget Department of Microbiology, University of Silesia, Jagiellońska 28, 40-032 Katowice, Poland

E-mail: anna.markowicz@us.edu.pl

Tel.: +480322009357

S. Borymski

E-mail: slawomir.borymski@us.edu.pl

Z. Piotrowska-Seget

E-mail: zofia.piotrowska-seget@us.edu.pl

G. Woźniak

Department of Geobotany and Nature Protection, University of Silesia, Jagiellońska 28, 40-032 Katowice, Poland

E-mail: gabriela.wozniak@us.edu.pl

D. Chmura

Institute of Environmental Protection and Engineering, University of Bielsko-Biała, Willowa 2, 43-309 Bielsko-Biała, Poland

E-mail: dchmura@ath.bielsko.pl the carbon-utilisation profiles. The mean proportion of microbe guilds in dominant plant patches accounts for $60 \%$ of the variance while the soil physicochemical parameters explained only $30 \%$ of the variance. This suggest that in post-industrial habitats the biotic features of the soil substratum are more important for the vegetation development than the abiotic parameters.

Keywords Vegetation development - Dominant plant species · Functional diversity · Microbial community · Community-level physiological profiles

\section{Introduction}

Coal mine spoil heaps are sites, where the stone material extracted together with the coal was stored. The spoil material does not contain organic carbon and the amounts of nitrogen and phosphorus are low (Ledin and Pedersen 1996). Moreover, these sites are also characterised by extreme abiotic conditions, e.g., lack of water, low nutrient availability, high temperature and high salinity (Bradshaw 2000; Mendez and Maier 2008; Woźniak 2010). Each of these limits biological activity and therefore the development of diverse microflora in this environment is very slow (Frouz et al. 2001; Urbanová et al. 2011). However, over time hard coal mine heaps, despite their adverse conditions, are effectively colonised by many plant and animal species, which promote the development of soil (Cohn et al. 2001; Woźniak et al. 2003; Rostański and Woźniak 2007; Chmura et al. 2011; Tropek et al. 2012). The spontaneous colonisation by living organisms on post-industrial sites represents a model situation of de novo ecosystem development. This provides opportunity for studying the structure of spontaneously established vegetation and relations between plants and rhizosphere microorganisms on coal mine heaps in succession process over a long period of time. The increase in plant diversity during vegetation development has been recorded in many studies 
(Whittaker 1965; Matthews 1979; Pineda et al. 1981) but the results of these studies did not show consistently how plant diversity changes during spontaneous succession. However, the species diversity of plant pioneer communities decreases with time because their composition is determined by chance in the initial phase of colonisation (Margalef 1968).

The variety of plants that were recorded among the sites and over time causes difficulties and often makes it impossible to detect repetitive patterns and relationships between the organisms and/or the habitat. One solution is to implement the concept of functional groups that was introduced in order to reduce the variety of organisms into a "relatively continuous feature space" sensu Box (1996); Smith et al. (1997); Duckworth et al. (2000). In this study we used the functional concept for both plants and microorganisms. This approach allows a better explanation and understanding of changes in an ecosystem in time-space than an analysis that is solely based on species composition (Pokorny et al. 2005; Dzwonko and Loster 2007; Cadotte et al. 2011; Woźniak et al. 2011; Wang and Chen 2013; Piekarska-Stachowiak et al. 2014). The plant functional groups (PFGs) concept means, that the analysis of vegetation is based on the number and participation of species with similar morphological and ecological characteristics, representing the same ecological feature. Some studies have shown that the PFGs composition of certain plant species may strongly affect the microbial functional diversity (Milcu et al. 2006; Zhang et al. 2011). There is an increasing understanding that plant succession is closely connected with the diversity and activity of soil microbial communities due to positive and negative feedbacks (Ehrenfeld et al. 2005; Bezemer et al. 2006; Kardol et al. 2007). The study on plant-microbial relations were mostly focused on natural reclaimed postindustrial sites (Tscherko et al. 2003; Šourková et al. 2005). Our knowledge of changes in microbial functional diversity in relation to plant succession on coal heaps is limited. Therefore, in this study changes in plant functional groups (PFGs) in relation to microbial functional groups (MFGs) were assessed. The microbial metabolic potential can be studied by community-level physiological profiles (CLPPs) that reflect microbial functional groups (MFGs). In this paper, the MFGs refer to groups with an ability to degrade specific carbon sources: carbohydrates, carboxylic acids, amino acids, polymers, amines and amides and miscellaneous (Zak et al. 1994; García-Palacios et al. 2011; Kenarova et al. 2014).

The aim of the study was to find any relations between plant functional groups (features of the dominant species): (1) life span (tree, biannual, perennial), (2) socioecological group (coniferous forest, ruderal habitat, deciduous forest), (3) potential mycorrhizal status (ectomycorrhiza, arbuscular mycorrhiza, absence of mycorrhiza) and the microbial activity expressed as the ability of bacterial communities to utilise compound such as carbohydrates, carboxylic acids, amino acids, polymers, amines and amides as well as miscellaneous on unreclaimed coal mine spoil heaps. We hypothesised that specific microbial functional groups are related to plant functional groups and not to individual plant species.

\section{Materials and methods}

\section{Study site}

The study was carried out on coal mine spoil heaps located in the Silesian Upland in southern Poland: Panewniki $\left(50^{\circ} 12^{\prime} 57 \mathrm{~N}, 18^{\circ} 53^{\prime} 56 \mathrm{E}\right)$, Mysłowice Wesoła $\left(50^{\circ} 10^{\prime} 29 \mathrm{~N}, 19^{\circ} 05^{\prime} 35 \mathrm{E}\right)$, Staszic $\left(50^{\circ} 13^{\prime} 20 \mathrm{~N}, 19^{\circ} 03^{\prime} 16 \mathrm{E}\right)$, Gliwice $\left(50^{\circ} 16^{\prime} 40 \mathrm{~N}, 18^{\circ} 41^{\prime} 28 \mathrm{E}\right)$, Brzeszcze $\left(49^{\circ} 58^{\prime} 45 \mathrm{~N}\right.$, $\left.19^{\circ} 11^{\prime} 26 \mathrm{E}\right)$, Silesia $\left(49^{\circ} 56^{\prime} 32 \mathrm{~N}, 1^{\circ} 01^{\prime} 11 \mathrm{E}\right)$, Knurów $\left(50^{\circ} 09^{\prime} 58 \mathrm{~N}, 19^{\circ} 41^{\prime} 55 \mathrm{E}\right)$. The heaps were divided into four age classes. The youngest class I was formed up to 10 years ago, class II - up to 30 years ago, class III - up to 60 years ago and class IV-more than 60 years ago. The spoil heaps were built of carboniferous gangue with unfavorable soil texture (mainly clay stone and siltstone, also sandstone, conglomerate, coal shale) a small admixtures of coal was also reported. Stones and gravel were present even on the oldest heaps covered with woodland vegetation. The chemical characteristics of the soil are presented in Table 1. The climate in the region is temperate with a mean annual precipitation of ca. $580 \mathrm{~mm}$ and a mean annual temperature of $7.6^{\circ} \mathrm{C}$.

\section{Vegetation sampling}

In a preliminary study a list of the most frequent species which were the dominant in vegetation patches for each age class of heap was prepared. A dominant species in this study was defined as a species whose cover abundance was higher than the cover of all other species in the studied vegetation patch. Plots $(2 \times 2 \mathrm{~m})$ were established in each of the four age classes based on the list of dominant species (three dominant species in three replicates). This was done in order to avoid sampling an accidentally chosen species, which can happen by using a totally random or systematic sampling design. In this sampling system, the study focused on the most frequent dominant species in the course of vegetation development during each time series (age class) of a heap. Samples of the same dominant species were taken from separate heaps of the same age class, at similar geographical locations in order not to change the abiotic characteristics. The plots were chosen by randomly stratifying the heaps for the dominant species on a heap of a particular age class. The cover of all species in the patch was assessed visually on a percentage scale with intervals of $10 \%$, except for those accompanying species that were below $10 \%$ for which cover levels of 1 and $5 \%$ were distinguished. The characteristics for all of the recoded dominant species in terms of their Raunkiaer's life form (Frank and Klotz 1990; Klotz et al. 2002), socio-ecological group (Zarzycki et al. 2002) 


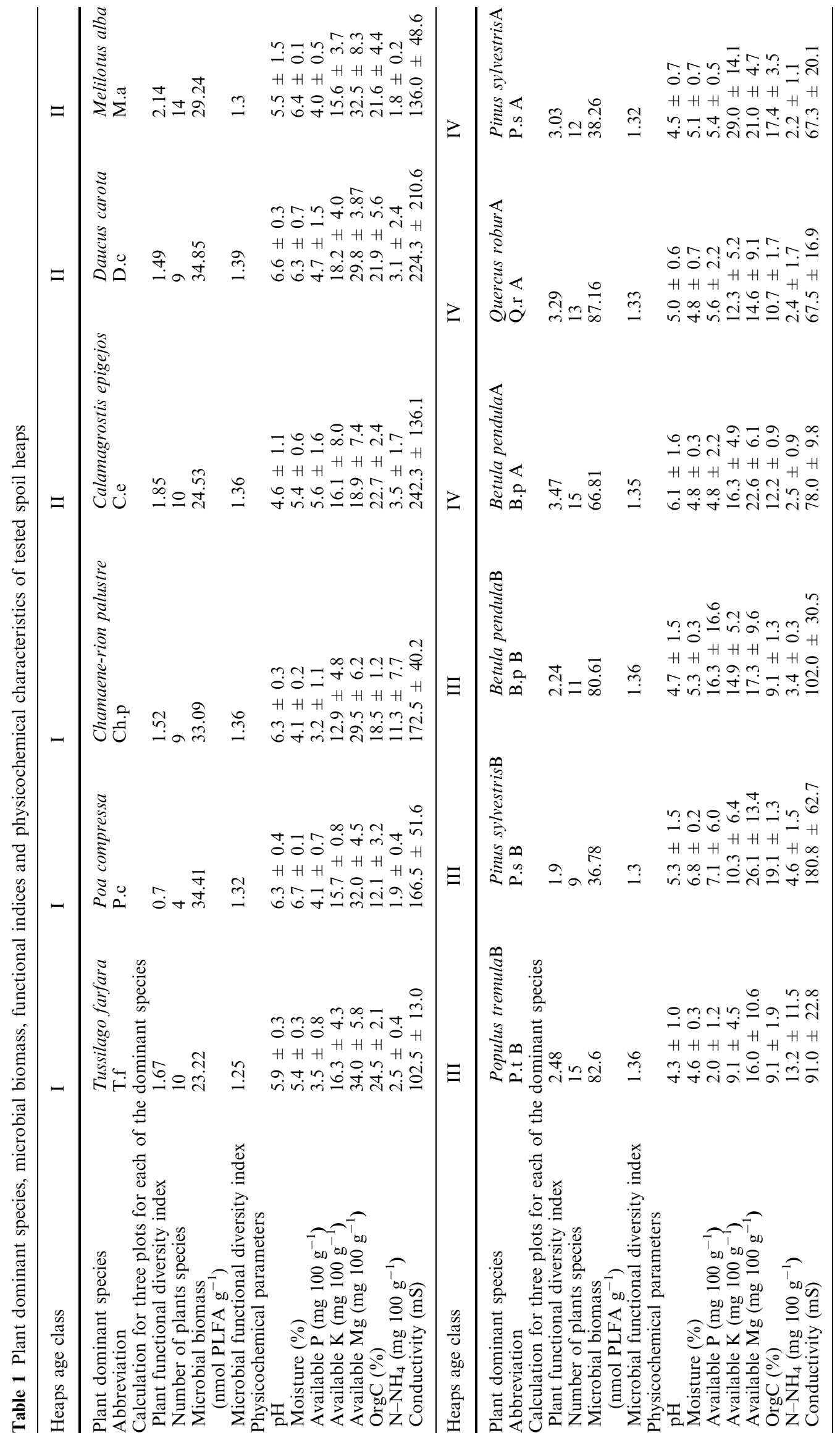




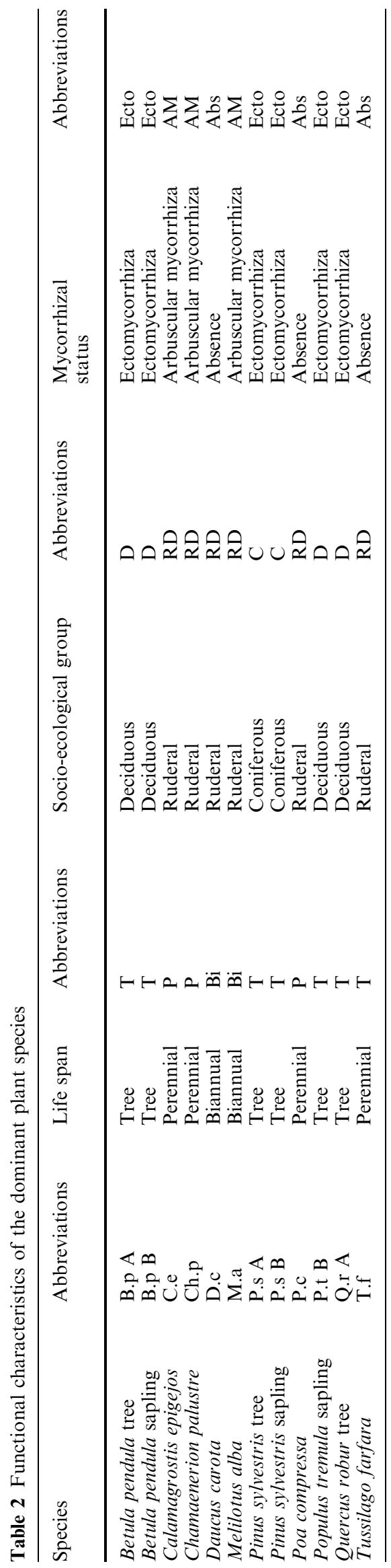

and potential to form mycorrhiza were determined as is shown in Table 2.

The analysis of soil physicochemical parameters

Composite soil samples consisting of five rhizosphere soil subsamples (in volume - core diameter $5 \mathrm{~cm}$, depth $15 \mathrm{~cm}$ ) were collected from the roots of the dominant species grown in the corners and in the middle of each of the 36 plots. Herbaceous plants were pulled from soil and the roots were shaken until most of the adhering soil was removed. The remaining soil particles were removed by mechanical brushing and were considered as rhizosphere. In the case of trees, their subsurface roots were excavated and fine roots with a tightly bound soil layer were carefully collected from five random sites of the root system. In order to minimise the variation between the rhizosphere soil samples, all of the samples were collected on the same day in July, 2010. The soil samples from each plot were combined air-dried (at room temperature) and sieved into a $2 \mathrm{~mm}$ fraction prior to sub-sampling for microbiological and soil chemical analyses. Soil moisture content was determined by the gravimetric difference between $10 \mathrm{~g}$ wet and dry weights $\left(105{ }^{\circ} \mathrm{C}\right.$ for $\left.24 \mathrm{~h}\right)$ of the soil samples. Soil $\mathrm{pH}$ was measured in $1 \mathrm{M} \mathrm{KCl}$ solution at a 1:10 soil:liquid ratio (w:v). $\mathrm{pH}$ and soil conductivity were measured using a digital pH-meter. Available potassium was extracted with ammonium fluoride- $\mathrm{HCl}$ at $\mathrm{pH} 2$ and measured with a flame photometer. Available magnesium was extracted with a $1.125 \mathrm{~N}$ sodium acetate solution at $\mathrm{pH} 4.2$ and analysed by atomic absorbance. Total phosphorus was measured using the calorimetric and the Tiurin method according to ISO standards (ISO 11263: 1994; ISO 14235:1998). Organic carbon content analysis was carried out using the standard loss on ignition (LOI) method (Wilke 2005). The ammonium nitrogen $\mathrm{N}-\mathrm{NH}_{4}$ and nitrate nitrogen ions were extracted with $0.01 \mathrm{M} \mathrm{CaCl}_{2}$ and measured separately using a reflectometer RQ Flex Merck. The microbial biomass was assessed using the phospholipid fatty acid method as described by Pennanen et al. (1996). The following PLFA biomarkers were assigned to major microbial groups: i15:0, a15:0, i16:0, i17:0, a17:0 for gram-positive bacteria, 16:1w7, 18:1w7, cy17:0, cy19:0 for gram-negative bacteria, 18:2w6,9 for fungi and 10Me17:0, 10Me18:0 for actinomycetes (Ehlers et al. 2010; Bird et al. 2011). Additionally, 15:0 and 17:0 fatty acid along with the above mentioned bacterial biomarkers were used to calculate the total bacterial PLFA biomass.

\section{Community level physiological profiles}

CLPPs were assessed using the Biolog system (Biolog Inc., CA, USA) and EcoPlates ${ }^{\mathrm{TM}}$ containing three sets of 31 carbon substrates and water blanks (Insam and Rangger 1997). Microorganisms were extracted from the soil as described by Zak et al. (1994). Briefly, soil sus- 
Table 3 The mean \pm SD of the relative use (in the percentage of total use on a plate) of carbohydrates, carboxylic acids, amino acids, polymers, amines and amides and miscellaneous that refer to the microbial functional groups

\begin{tabular}{|c|c|c|c|c|c|c|}
\hline & Amines and amides & Amino acids & Carbohydrates & Carboxylic acids & Miscellaneous & Polymers \\
\hline \multicolumn{7}{|l|}{ Socio-ecological group } \\
\hline Deciduous & $36.1 \pm 11.4 \mathrm{a}$ & $29.7 \pm 3.7 \mathrm{a}$ & $41.7 \pm 2.5 \mathrm{a}$ & $21.7 \pm 3.2 \mathrm{a}$ & $22.9 \pm 4.3 \mathrm{a}$ & $33.8 \pm 4.5 a$ \\
\hline Coniferous & $12.3 \pm 2.3 b$ & $21.6 \pm 1.1 \mathrm{~b}$ & $42.7 \pm 3.9 \mathrm{a}$ & $15.7 \pm 2.0 \mathrm{~b}$ & $13.0 \pm 1.3 b$ & $25.5 \pm 1.2 b$ \\
\hline Ruderal & $18.1 \pm 10.0 \mathrm{~b}$ & $18.2 \pm 3.1 \mathrm{c}$ & $28.7 \pm 8.9 b$ & $11.7 \pm 3.6 \mathrm{c}$ & $11.1 \pm 2.6 b$ & $21.6 \pm 6.8 b$ \\
\hline \multicolumn{7}{|l|}{ Life span } \\
\hline Biannual & $19.9 \pm 5.5$ & $18.6 \pm 3.1 b$ & $32.6 \pm 6.6 b$ & $12.3 \pm 2.3 b$ & $10.8 \pm 1.6 b$ & $22.4 \pm 6.9 b$ \\
\hline Perennial & $17.2 \pm 11.8$ & $18.0 \pm 3.2 b$ & $26.8 \pm 9.5 b$ & $11.5 \pm 4.2 b$ & $11.3 \pm 3.0 \mathrm{~b}$ & $21.2 \pm 7.0 \mathrm{~b}$ \\
\hline Tree & $28.2 \pm 14.8$ & $27.0 \pm 5.0 \mathrm{a}$ & $42.1 \pm 2.9 \mathrm{a}$ & $19.7 \pm 4.1 \mathrm{a}$ & $19.6 \pm 6.0 \mathrm{a}$ & $31.0 \pm 5.4 \mathrm{a}$ \\
\hline \multicolumn{7}{|l|}{ Mycorrhizal status } \\
\hline Ectomycorrhiza & $28.5 \pm 16.3$ & $27.2 \pm 5.4 \mathrm{a}$ & $42.5 \pm 3.1 \mathrm{a}$ & $19.5 \pm 4.3 \mathrm{a}$ & $20.0 \pm 6.5 a$ & $31.4 \pm 5.8 \mathrm{a}$ \\
\hline Arbuscular mycorrhiza & $19.1 \pm 12.2$ & $19.9 \pm 4.8 b$ & $29.3 \pm 11.0 \mathrm{~b}$ & $14.6 \pm 5.2 b$ & $12.6 \pm 3.8 b$ & $23.7 \pm 7.3 b$ \\
\hline Absence of mycorrhiza & $19.8 \pm 5.6$ & $18.5 \pm 2.7 b$ & $31.8 \pm 6.3 b$ & $10.8 \pm 2.8 b$ & $11.2 \pm 2.6 b$ & $21.3 \pm 6.2 b$ \\
\hline
\end{tabular}

The different letters indicate significant differences between the plant functional groups that were distinguished at $P<0.05($ ANOVA followed by the Tukey test or Kruskal-Wallis test followed by Conover test)

pensions $(10 \mathrm{~g}$ dry weight of soil in $90 \mathrm{~mL}$ sterile $0.85 \%$ $\mathrm{NaCl}$ solution) were shaken for $1 \mathrm{~h}$, and after that, aliquots of $125 \mathrm{~mL}$ were inoculated on plates, which were then incubated at $24{ }^{\circ} \mathrm{C}$ in the dark. The readings were taken after inoculation and at $12 \mathrm{~h}$ intervals for $144 \mathrm{~h}$ using a microplate reader (Victor ${ }^{\mathrm{TM}}$ X5 Multilabel Plate Readers, PerkinElmer). The absorbance measurements for individual substrates were corrected against the control well containing only water and by subtracting the absorbance of the first reading for elimination of the background absorbance (Insam and Rangger 1997). The corrected absorbance values were used to calculate the area under the curve (AUC) and the average area under the curve (AAUC) which was used to express the overall microbial activity on the plates. In order to distinguish the microbial functional groups, the substrates were grouped into six guilds - carbohydrates, carboxylic acids, amino acids, polymers, amines and amides and miscellaneous (Zak et al. 1994). The carbon substrate guilds refer to microbial functional groups understood as groups with an ability to utilise specific carbon sources. The AUC values of the substrates for each guild were summarised and expressed as a percentage of the total AUC value of the plate. The AUC approach has been suggested to measure the proportional substrate utilisation efficiency unaffected by inoculum density (Preston-Mafham et al. 2002). The following microbial indices - substrate richness $\left(R_{\mathrm{S}}\right)$, the functional diversity index based on the Shannon-Wiener biodiversity index $\left(H^{\prime}\right)$ and the index of evenness $\left(I^{\prime}\right)$ were calculated according to the equations $H^{\prime}=-\Sigma \mathrm{pi}(\operatorname{lnpi})$ and $I^{\prime}=H^{\prime} / \ln R_{\mathrm{s}}$, respectively, where pi is the ratio of the activity on each substrate (ODi) to the sum of activities on all substrates ( $\Sigma \mathrm{ODi}$ ) and $R_{\mathrm{S}}$ is the number of oxidised $\mathrm{C}$ substrates. The indices were used in the statistical analyses.

\section{Data analysis}

An analysis of variance (ANOVA) was used to investigate the statistical differences among the microbial functional groups. In order to determine which PFGs were responsible for the differences, the Tukey post hoc test was performed. When the data did not meet the assumptions for the parametric tests, the KruskalWallis or Conover test was used. The normality of distribution was checked using the Shapiro-Wilk test and the homogeneity of variance was analysed using the Levene test. Cluster analysis (various indices of distance and the Ward method) was performed in order to show the ecological distance in MFGs between the samples assigned to particular dominant plant species (R Core Team 2014). Prior to this analysis, means of distinguished MFGs for particular dominant plant species and means of soil data were calculated. The choice of distance measured in clustering followed the method described by Oksanen (2011). The following distance measures were defined-Euclidean, Bray-Curtis dissimilarity, City Block Manhattan and Jaccard. Next, the function rankindex (Vegan software) was used to examine which of the measures best separated the samples along known gradients expressed as a matrix of soil data. In order to study differentiation of MFGs along possible gradients: dominant plant species and soil variables, direct (constrained) ordination redundancy analysis (RDA) was carried out (Ter Braak and Šmilauer 2002). For the RDA the means of the relative use of different carbon sources that refer to the microbial functional groups were used. The Monte Carlo test $(999$ permutations) was performed in order to estimate significance of the model and particularly significance of each used factor. In this end, pseudo- $F$ and value of probability was computed.

\section{Results}

\section{Vegetation}

The species composition and cover abundance on 36 plots were recorded (Table S1). In total 99 plant species were identified. Among the 12 dominant species that were studied, there were two entries for $\operatorname{Betula}(\mathrm{A}, \mathrm{B})$ 
and Pinus (A, B), which were the dominants as both saplings (B) and trees (A). In this paper, these two species were treated as four separate entities because they represented different developmental phases and therefore played different roles in the succession stage that was being studied (Table 2).

\section{Microbiological studies}

There were significant differences $(P<0.05)$ between MFGs in the soil substrate of the vegetation patches that were dominated by species representing deciduous forest habitats and patches that were dominated by species representing coniferous forests and ruderal habitats (Table 3). In case of amino acids and carboxylic acids substantial differences were found among all types of habitats. The analysis of the guilds indicated significant differences in the relative use of carbohydrates, amino acids, carboxylic acids, miscellaneous and polymers among trees as compared to biannual and perennial plants (Table 3). Significant differences were observed between patches dominated by species that commonly form ectomycorrhiza and the patches that were dominated by non-mycorrhizal species or those that interact with arbuscular fungi (Table 3 ). The only exception was observed for amines and amides, for which the degradation was similar for all distinguished PFGs. Metabolic activity on the Biolog EcoPlates ${ }^{\mathrm{TM}}$, expressed as AAUC, did not increase gradually with the age of the heap. However, AAUC was very high in soils under deciduous trees, in particular under birch (tree layer and shrub layer) and oak trees (tree layer) (data not shown). The lowest AAUC was measured for soil under Chamaenerion palustre, which represented the perennial life span (Table 2). There were significant differences $(P<0.05)$ in the MFGs among soil samples influenced by analysed dominants. Carbohydrates was preferably utilised in all of the tested soil samples, with the exception of soil from the ruderal species Calamagrostis epigejos. The relative use of carbohydrates was less than $40 \%$ in soils under Ch. palustre, C. epigejos, Populus tremula B, Betula pendula (tree layer) and (shrub layer), and Quercus robur. The function rankindex revealed that the Manhattan city block distance best separated samples of MFGs, along the physicochemical soil properties, scoring the highest value 0.15 followed by the remaining distances which ranged from 0.04 to 0.13 . There were two main clusters - one with deciduous trees and a second, more complex one, with the remaining species and $C h$. palustre as an outlying group (Fig. 1). The two biggest groups of the second cluster were mostly herbaceous plants, but the species recorded on the heaps of the first ( $P$. compressa, Tussilago farfara) and second (C. epigejos, Daucus carota, Melilotus alba) age classes were mixed. The vegetation patches that were dominated by $P$. sylvestris in the tree (A) and shrub (B) layers were in a separate group (Fig. 1).

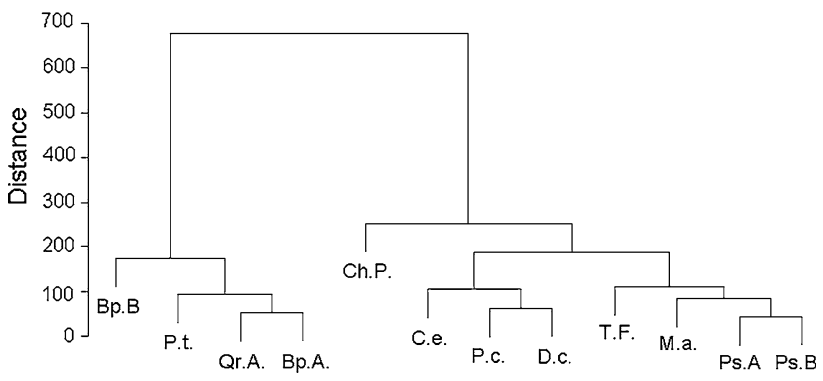

Fig. 1 Cluster analysis of the mean proportion of microbe guilds in plant dominant patches (Manhattan city block, Ward method). Plant dominant species: B.p A Betula pendula tree, B.p B: Betula pendula shrub, C.e: Calamagrostis epigejos, Ch.p: Chamaenerion palustre, D.c: Daucus carota, M.a: Melilotus alba, P.s A: Pinus sylvestris tree, P.s B: Pinus sylvestris shrub, P.c: Poa compressa, P.t B: Populus tremula shrub, Q.r A: Quercus robur tree, T.f: Tussilago farfara

The redundancy analysis (Fig. 2) illustrates that among the environmental parameters only conductivity $(12 \%$ of variance explained, pseudo- $F=4.78$, $P=0.001)$ and the content of magnesium $(8 \%$ of variance explained, pseudo- $F=3.25, P=0.006$ ) were significant explanatory variables in the soil substratum. The gradient of magnesium content influence microbial functional groups associated with some perennial and biennial plant dominants and is associated with nonmycorrhizal plants, whereas high salinity (C25) is confined to microbial functional groups associated with some non-mycorrhizal, biennial plants of ruderal habitats (Fig. 2). However, these soil properties did not explain the proportion of MFGs among tested samples. The data illustrated in diagram (Fig. 2) accounts for $30 \%$ of the variance in the microbial data.

\section{Discussion}

In our study, a distinct increase in the plant functional diversity (measured as the mean values for plots from spoil heaps of the same age class) was recorded during heap succession development (Table 1). Previous studies found that the plant diversity is connected with the functioning of soil microorganisms and the changes in PFGs may have a stronger impact on microbial communities than the plant species per se (Vinton and Burke 1995; Groffman et al. 1996; Kennedy et al. 2005). He et al. (2008) found no direct links between plant and microbial taxonomic diversity. However, they noted that plant diversity was positively correlated with bacterial metabolic diversity. Our results showed that microbial community on the youngest heaps exhibited less activity than those from the older heaps. The spoil material of unreclaimed coal mine heaps is characterised by a low microbial cell density and biological activity (Frouz et al. 2001; Frouz and Nováková 2005). Growing activity may be a result of a gradual increase of organic $\mathrm{C}$ and microbial biomass (Rǔžek et al. 2001; Šourková et al. 2005). In our 

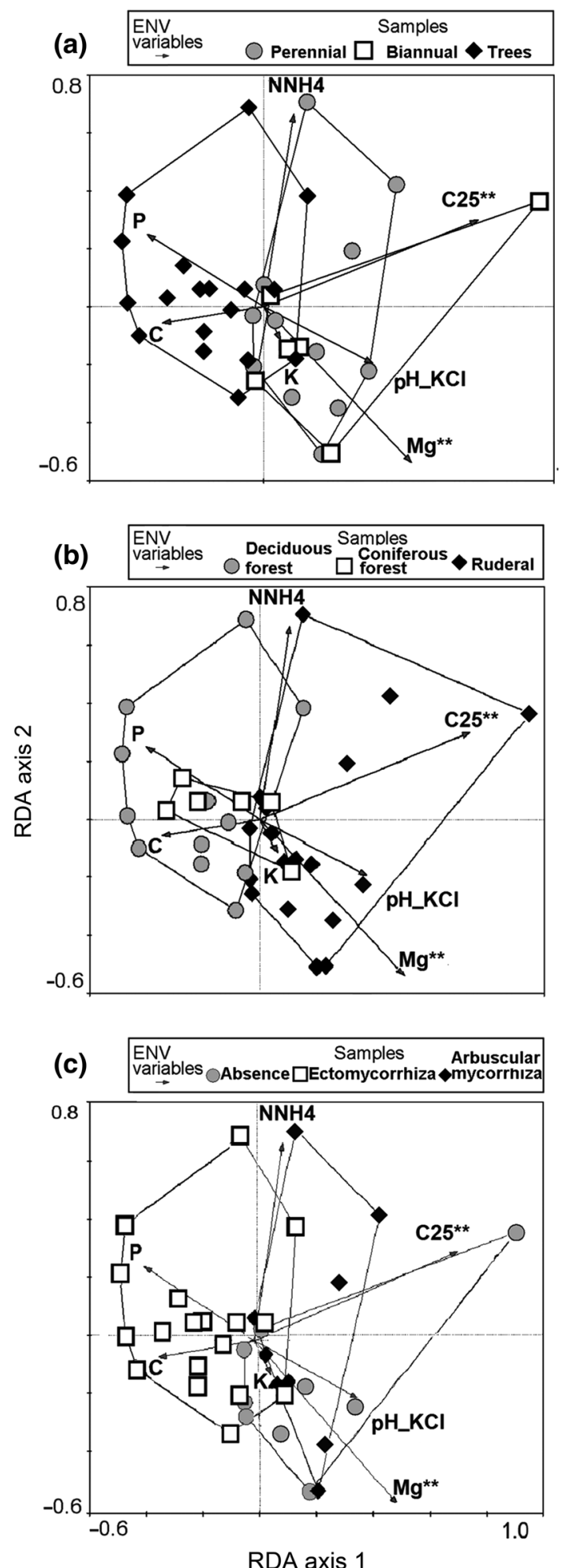

Fig. 2 Redundancy analysis (RDA) ordination of mean proportion of microbial guilds in the gradient of selected physicochemical parameters. The three versions demonstrated various projections of samples based on classification to the particular plant functional groups a lifespan, b habitat type, c mycorrhizal status. Environmental variables: $\mathrm{pH} \mathrm{KCl}$ : $\mathrm{pH}$ value, $\mathrm{N}-\mathrm{NH}_{4}$ : ammonium nitrogen content, $\mathrm{Mg}$ : available magnesium, $\mathrm{C} 25$ : conductivity, $\mathrm{C}$ : organic carbon, $\mathrm{P}$ : total phosphorus. ${ }^{* *} P<0.01$ study the content of organic carbon was high with the highest amount on the heaps of age class II (Table 1). Such a high level of organic carbon is connected with the presence of geogenic carbon, which originates from particles of hard coal from the tertiary strata. This geogenic carbon is not available to microorganisms, and therefore, despite the high total organic carbon content, the tested soils are poor in accessible carbon sources and provide harsh conditions for microorganisms and plant growth (Skarżyńska 1997).

The microbial biomass increased with the age of the heaps however, it was dependent on plant dominant species (Table 1). Although we did not observe an increase in the microbial functional diversity index, there was a gradual increase in the plant functional diversity (Table 1). In contrast, other authors have reported that the functional diversity index is correlated with organic carbon content and microbial biomass (Schipper et al. 2001; Oren and Steinberger 2008). The absence of such correlations in this study may be due to the significant influence of specific environmental factors such as lack of water, low nutrient availability, high temperature and high salinity on the microbial functional diversity. Nunan et al. (2005) when analysing root associated communities of several grasses found that the microbial fingerprints showed a high degree of similarity between tested species. However, a statistical analysis of the data indicated that topography had a significant influence on microbial community composition. Additionally, studies by Sprocati et al. (2014) on microbial biodiversity from mining sites across Europe showed, that biodiversity at phylum level, was correlated to soil factors like the presence of heavy metals and harsh soil conditions (extreme $\mathrm{pH}$, lack of nutrients) while, at species level, reflects a remarkable local characteristics. Moreover, Mastrogianni et al. (2014) who analysed the dynamics of soil microflora after reclamation of coal mine areas, found that the carbon utilisation profiles exhibited complex successional patterns, where the highest functional diversity and activity were observed in the earlier successional stages.

In our study the cluster analysis showed that among socio-ecological groups, common features were observed for species representing coniferous forests and ruderal habitats. Such a result could be expected to some extent but the positioning of samples from $P$. sylvestris A - tree and $\mathrm{B}$ - shrub and pioneer vegetation ( $T$. farfara, $C h$. palustre, $P$. compressa) in the cluster analysis is surprising. This analysis also revealed that Ch. palustre is a species that is associated with a specific microbial community. This might be explained by the fact that this species frequently grows on ruderal habitats in the Silesian region, although it originates from the embankments of high mountain rivers (Rostański and Woźniak 2007). The close position of P. sylvestis A and B with M. alba and T. farfara samples suggests that the age of the heap and consequently the successional stage does not appear to be the most important for the development of the microbial-plant relations. Microbial 
communities under dominant species that represent biennials and perennials revealed similarities in their utilisation of carbon substrates. This suggested that the frequent presence of short-lived therophytes in the early stage of vegetation development might result from links between these plants and the microbial metabolic potential. The high participation of the therophytes and their persistence in harsh habitats is connected with their tolerance to stress conditions and the positive influence of microorganisms on nutrient cycling and soil formation thus promote plant development (Martinez-Ruiz and Marrs 2007). It has been also accepted that mycorrhiza is beneficial for the plants that live in harsh habitats (Pawłowska et al. 1996, 2000; van der Heijden et al. 1998). Among the dominant species recorded on the heaps representing the first age class, only one of these, Ch. palustre, is reported as living with arbuscular mycorrhiza, while among the species recorded on the heaps of the second age class, two species are known to live with the arbuscular mycorrhiza. This symbiosis is particularly important because fungi have been shown to ensure the transport of assimilates and nutrients between plants (Heap and Newman 1980; Martins 1993; Pawłowska et al. 1996). Grime et al. (1987) suggested that such transport between the roots of dominant and subordinate species within a plant community acts as a mechanism that determines the plant community structure (Püschel et al. 2007; Bonfante and Anca 2009). In our study, with the exception of the amines and amides, the utilisation profiles were similar for the soil microbial communities of the dominant species with the arbuscular mycorrhiza and those with no mycorrhiza. This may be explained by the fact that mycorrhiza colonisation can relate to about $90 \%$ vascular plants species in natural ecosystems (Brundett 1991; Read et al. 1992; Bonfante and Anca 2009). On the other hand, Nicolson (1960) suggested that the low level of the colonisation rate or lack of mycorrhizal fungi may be related to the initial process of ecological succession and that the percentage of mycorrhizal plants increases along the succession. This mycorrhizal phenomenon has been observed on areas that have been heavily degraded by industrial activity (Turnau et al. 1993, 1996, 2001; Pawłowska et al. 1996).

The results of our study suggest that in post-industrial habitats like coal mine heaps the biotic features of the soil substratum and therefore the plant-soil biota feedback are more important for the vegetation development than the abiotic parameters. A multivariate analysis of CLPPs indicated that microbial functional groups account for twice as much variance in PFGs as tested physicochemical parameters and among them the most important were conductivity and magnesium content. The mycorrhizal status had the greatest effect on the microbial metabolic potential. The MFGs provide an indication of the activity of microorganisms that are relevant to the cycling of nutrients in harsh ecosystems such as coal mine heaps. However, plant-soil feedback must be carefully tested because it has been stated that nutrient and light availability are the major driving forces of plant species turnover during successional development (Tilman 1988; Grime 2001). It has been shown that plants may exert species-specific effects on both abiotic and biotic soil properties and that these relationships may develop relatively quickly, i.e., within two growing seasons. The complexity of these interactions was confirmed by a meta-analysis. The analysis revealed that simple generalisation on the interplay among PFGs, MFGs and ecosystem properties or the trophic level will be difficult to sustain (Balvanera et al. 2006).

Acknowledgments The study was supported by Grant No. N305 046336 from the Polish Ministry of Science and Higher Education.

Open Access This article is distributed under the terms of the Creative Commons Attribution 4.0 International License (http:// creativecommons.org/licenses/by/4.0/), which permits unrestricted use, distribution, and reproduction in any medium, provided you give appropriate credit to the original author(s) and the source, provide a link to the Creative Commons license, and indicate if changes were made.

\section{References}

Balvanera P, Pfisterer A, Buchmann N, He J, Nakashizuka T, Raffaelli D, Schmid B (2006) Quantifying the evidence for biodiversity effects on ecosystem functioning and services. Ecol Lett 9:1146-1156

Bezemer TM, Lawson CS, Hedlund K, Edwards AR, Brook AJ, Igual JM, Mortimer SR, Van der Putten WH (2006) Plant species and functional group effects on abiotic and microbial soil properties and plant-soil feedback responses in two grasslands. J Ecol 94:893-904

Bird JA, Herman DJ, Firestone MK (2011) Rhizosphere priming of soil organic matter by bacterial groups in a grassland soil. Soil Biol Biochem 43:718-725

Bonfante P, Anca IA (2009) Plants, mycorrhizal fungi, and bacteria: a network of interactions. Annu Rev Microbiol 63:363-383

Box EO (1996) Plant functional types and climate at the global scale. J Veg Sci 7:309-320

Bradshaw AD (2000) The use of natural processes in reclamation-advantages and difficulties. Landsc Urban Plan 51:89-100

Brundett MC (1991) Mycorrhizas in natural ecosystems. Adv Ecol Res 21:171-313

Cadotte M, Carscadden K, Mirotchnick N (2011) Beyond species: functional diversity and the maintenance of ecological processes and services. J Appl Ecol 48:1079-1087

Chmura D, Molenda T, Błońska A, Woźniak G (2011) Sites of leachate inflows on coalmine heaps as refuges of rare mountainous species. Pol J Environ Stud 20:551-557

Cohn EV, Rostański A, Tokarska-Guzik B, Trueman IC, Woźniak G (2001) The flora and vegetation of an old solvay process tip in Jaworzno (Upper Silesia, Poland). Acta Soc Bot Pol 70:47-60

Duckworth JC, Kent M, Ramsay PM (2000) Plant functional types: an alternative to taxonomic plant community description in biogeography? Prog Phys Geog 24:515-542

Dzwonko Z, Loster S (2007) A functional analysis of vegetation dynamics in abandoned and restored limestone grasslands. J Veg Sci 18:203-212

Ehlers K, Bakken LR, Frostegård Å, Frossard E, Bünemann EK (2010) Phosphorus limitation in a Ferralsol: impact on microbial activity and cell internal $\mathrm{P}$ pools. Soil Biol Biochem 42:558-566

Ehrenfeld JG, Ravit B, Elgersma K (2005) Feedback in the plantsoil system. Annu Rev Env Resour 30:75-115 
Frank D, Klotz S (1990) Biologisch-ökologische Daten zur Flora der DDR. Martin Luther Universität, Wissenschaftliche Beiträge 32:1-167

Frouz J, Nováková A (2005) Development of soil microbial properties in top soil layer during spontaneous succession in heaps after brown coal mining in relation to soil microstructure development. Geoderma 129:54-64

Frouz J, Keplin B, Pižl V, Tajovský K, Starý J, Lukešová A Nováková A, Balík V, Háněl L, Materna J, Düker C, Chalupský J, Rusek J, Heinkele T (2001) Soil biota and upper soil layers development in two contrasting post-mining chronosequences. Ecol Eng 17:275-284

García-Palacios P, Bowker MA, Chapman SJ, Maestre FT, Soliveres S, Gallardo A, Valladares F, Guerrero C, Escudero A (2011) Early-successional vegetation changes after roadside prairie restoration modify processes related with soil functioning by changing microbial functional diversity. Soil Biol Biochem 43:1245-1253

Grime JP (2001) Plant strategies, vegetation processes, and ecosystem properties, 2nd edn. Wiley, Chichester

Grime JP, Mackey JML, Hillier SH, Read DJ (1987) Floristic diversity in a model system using experimental microcosms. Nature 328:420-422

Groffman PM, Eagan P, Sullivan WM, Lemunyon JL (1996) Grass species and soil type effects on microbial biomass and activity. Plant Soil 183:61-67

He X-Y, Wang K-L, Zhang W, Chen Z-H, Zhu Y-G, Chen H-S (2008) Positive correlation between soil bacterial metabolic and plant species diversity and bacterial and fungal diversity in a vegetation succession on Karst. Plant Soil 307:123-134

Heap A, Newman E (1980) Links between roots by Hyphae of vesicular-arbuscular mycorrhizas. New Phytol 85:169-171

Insam H, Rangger A (1997) Microbial communities: functional versus structural approaches. Springer, Berlin

ISO 11263 (1994) Soil quality-determination of phosphorus - spectrometric determination of phosphorus soluble in sodium hydrogen carbonate solution. International Standardization Organization

ISO 14235 (1998) Soil quality-determination of organic carbon in soil by sulfochromic oxidation. International Standardization Organization

Kardol P, Cornips NJ, van Kempen ML, Bakx-Shotman JM, Van der Putten WH (2007) Microbe mediated plant-soil feedback causes historical contingency effects in plant community assembly. Ecol Monogr 77:147-162

Kenarova A, Radeva A, Traykov I, Boteva S (2014) Community level physiological profiles of bacterial communities inhabiting uranium mining impacted sites. Ecotoxicol Environ Safe 100:226-232

Kennedy N, Edwards S, Clipson N (2005) Soil bacterial and fungal community structure across a range of unimproved and semiimproved upland grasslands. Microb Ecol 50:463-473

Klotz S, Kühn I, Durka W (2002) Biolflor - Eine Datenbank mit biologisch-ökologischen Merkmalen zur Flora von Deutschland. Bundesamt für Naturschutz, Bonn-Bad Godesberg. Schriftreihe für Vegetationskunde 38

Ledin M, Pedersen K (1996) The environmental impact of mine wastes - roles of microorganisms and their significance in treatment of mine wastes. Earth Sci Rev 41:67-108

Margalef R (1968) Perspectives in ecological theory. University Chicago Press, Chicago

Martinez-Ruiz C, Marrs RH (2007) Some factors affecting successional change on uranium mine wastes: insights for ecological restoration. Appl Veg Sci 10:333-342

Martins MA (1993) The role of the external mycelium of arbuscular mycorrhizal fungi in the carbon transfer process between plants. Mycol Res 97:807-810

Mastrogianni A, Papatheodorou EM, Monokrousos N, Menkissoglu-Spiroudi U, Stamou GP (2014) Reclamation of lignite mine areas with Triticum aestivum: the dynamics of soil functions and microbial communities. Appl Soil Ecol 80:51-59
Matthews JA (1979) A study of the variability of some successional and climax plant assemblage-types using multiple discriminant analysis. J Ecol 67:225-271

Mendez MO, Maier M (2008) Phytostabilization of mine tailings in arid and semiarid environments - an emerging remediation technology. Environ Health Persp 116:278-283

Milcu A, Partsch S, Langel R, Scheu S (2006) The response of decomposers (earthworms, springtails and microorganisms) to variations in species and functional group diversity of plants. Oikos 112:513-524

Nicolson TH (1960) Mycorrhizae in the Gramineae. II. Development in different habitats particulary sand dunes. Trans Brit Mycol Soc 43:132-145

Nunan N, Daniell TJ, Singh BK, Papert A, McNicol JW, Prosser JI (2005) Links between plant and rhizoplane bacterial communities in grassland soils, characterized using molecular techniques. Appl Environ Microbiol 71:6784-6792

Oksanen J, Blanchet FG, Kindt R, Legendre P, Minchin PR (2011) vegan: Community Ecology Package. R package version 20-1 http://CRAN.R-project.org $/$ package $=$ vegan. Accessed 24 Sept 2012

Oren A, Steinberger Y (2008) Catabolic profiles of soil fungal communities along a geographic climatic gradient in Israel. Soil Biol Biochem 40:2578-2587

Pawłowska TE, Błaszkowski J, Ruhling Å (1996) The mycorrhizal status of plants colonizing a calamine spoil mound in southern Poland. Mycorrhiza 6:499-505

Pawłowska TE, Chaney RL, Chin L, Charvat I (2000) Effects of metal phytoextraction practices on the indigenous community of arbuscular mycorrhizal fungi at a metal-contaminated landfill. Appl Environ Microbiol 66:2526-2530

Pennanen T, Frostegård A, Fritze H, Bååth E (1996) Phospolipid fatty acid composition and heavy metal tolerance of soil microbial communities along two heavy metal-polluted gradients in coniferous forests. Appl Environ Microbiol $62: 420-428$

Piekarska-Stachowiak A, Szary M, Ziemer B, Besenyei L, Woźniak G (2014) An application of the plant functional group concept to restoration practice on coal mine spoil heaps. Ecol Res 29:843-853

Pineda FD, Nicolas JP, Ruiz M, Peco B, Bernaldez FG (1981) Ecological succession in oligotrophic pastures of central Spain. Vegetatio 44:165-176

Pokorny ML, Sheley RL, Zabinski CA, Engel RE, Svejcar TJ, Borkowski JJ (2005) Plant functional group diversity as a mechanism for invasion resistance. Restor Ecol 13:448-459

Preston-Mafham J, Boddy L, Randerson PF (2002) Analysis of microbial community functional diversity using sole-carbonsource utilization profiles - a critique. FEMS Microbiol Ecol 42:1-14

Püschel D, Rydlová J, Vosátka M (2007) The development of arbuscular mycorrhiza in two simulated stages of spoil-bank succession. Appl Soil Ecol 35:363-369

R Core Team (2014) R: a language and environment for statistical computing. R Foundation for Statistical Computing, Vienna, Austria. http://www.R-project.org/

Read DJ, Lewis DH, Fitter AH, Alexander IJ (1992) Mycorrhiza in ecosystems. CAB International, Oxford

Rostański A, Woźniak G (2007) Grasses (Poaceae) on post-industrial waste sites in course of spontaneous succesion. Fragm Flor Geobot Pol Suppl 9:31-42

Růžek L, Voříšek K, Sixta J (2001) Microbial biomass-C in reclaimed soil of the Rhineland (Germany) and the North Bohemian lignite mining areas (Czech Republic): measured and predicted values. Restol Ecol 9:370-377

Schipper LA, Degens BP, Sparling GP, Duncan LC (2001) Changes in microbial heterotrophic diversity along five plant successional sequences. Soil Biol Biochem 33:2093-2103

Shugart HH, Woodward FI (1997) Plant functional types and their relevance to ecosystem properties and global change. In: Smith TM, Shugart HH, Woodward FI (eds) Plant functional types 
and their relevance to ecosystem properties and global change. International Geosphere-Biosphere Programme book series. Cambridge University Press, Cambridge

Skarżyńska KM (1997) Odpady powęglowe i ich zastosowanie w inżynierii lądowej i wodnej. Wydawnictwo Akademii Rolniczej, Kraków (in Polish)

Šourková M, Frouz J, Fettweis U, Bens O, Hüttl RF, Šantrůčková H (2005) Soil development and properties of microbial biomass succession in reclaimed post mining sites near Sokolov (Czech Republic) and near Cottbus (Germany). Geoderma 129:73-80

Sprocati AR, Alisi C, Tasso F, Fiore A, Marconi P, Langella F, Haferburg G, Nicoara A, Neagoe A, Kothe E (2014) Bioprospecting at former mining sites across Europe: microbial and functional diversity in soils. Environ Sci Pollut Res 21:6824-6835

Ter Braak CJF, Šmilauer P (2002) CANOCO reference manual and canodraw for windows user's guide: software for canonical community ordination (version 4.5). Microcomputer Power, Ithaca

Tilman D (1988) Plant strategies and the dynamics and structure of plant communities. Princeton University Press, New Jersey

Tropek R, Kadlec T, Hejda M, Kocarek P, Skuhrovec J, Malenovsky I, Vodka S, Spitzer L, Banar P, Konvicka M (2012) Technical reclamations are wasting the conservation potential of post-mining sites. A case study of black coal spoil dumps. Ecol Eng 43:13-18

Tscherko D, Rustemeier J, Richter A, Wanek W, Kandeler E (2003) Functional diversity of the soil microflora in primary succession across two glacier forelands in the Central Alps. Eur J Soil Sci 54:685-696

Turnau K, Kottke I, Oberwinkler F (1993) Element localization in mycorrhizal roots of Pteridium aquilinum (L.) Kuhn collected from experimental plots treated with cadmium dust. New Phytol 123:313-324

Turnau K, Miszalski Z, Trovelot A, Bonfante P, Gianninazzi S (1996) Oxalis acetosella as a monitoring plant on highly polluted soils. In: Azcon-Aguilar C, Barea JM (eds) Mycorrhizas in integrated systems: from genes to plant development. European Commission, EUR 16728, Luxembourg, pp 483-4864

Turnau K, Ryszka P, Gianinazzi-Pearson V, Van Tuinen D (2001) Identification of arbuscular mycorrhizal fungi in soils and roots of plants colonizing zinc wastes in Southern Poland. Mycorrhiza 10:169-174
Urbanová M, Kopecký J, Valásková V, Ságová-Marecková M, Elhottová D, Kyselková M, Moënne-Loccoz Y, Baldrian P (2011) Development of bacterial community during spontaneous succession on spoil heaps after brown coal mining. FEMS Microbiol Ecol 78:59-69

van der Heijden MGA, Klironomos JN, Ursic M, Moutoglis P, Streitwolf-Engel R, Boller T, Wiemken A, Sanders IR (1998) Mycorrhizal fungal diversity determines plant biodiversity, ecosystem variability and productivity. Nature 396:69-72

Vinton MA, Burke IC (1995) Interactions between individual plant species and soil nutrient status in shortgrass steppe. Ecology 76:1116-1133

Wang H, Chen H (2013) Plant functional groups based on vegetative and reproductive traits in a subtropical forest community. J Forest Res 18:481-490

Whittaker RH (1965) Dominance and diversity in land plant communities. Science 147:250-260

Wilke BM (2005) Determination of chemical and physical soil properties. In: Margesin R, Schinner F (eds) Manual of soil analysis-monitoring and assessing soil bioremediation. Springer, New York, pp 47-95

Woźniak G (2010) Diversity of vegetation on coal-mine heaps of the Upper Silesia (Poland). In: Margesin R, Schinner F (eds) Manual of soil analysis - monitoring and assessing soil bioremediation. Szafer Institute of Botany. Polish Academy of Science, Kraków, p 310 (in Polish)

Woźniak G, Pasierbiński A, Rostański A (2003) The diversity of spontaneous woodland vegetation on coals mine heaps of Upper-Silesian industrial region. Arch Environ Prot 29:93-105

Woźniak G, Chmura D, Błońska A, Sierka E, Tokarska-Guzik B (2011) Applicability of the concept of functional groups for analysis of spatiotemporal vegetation changes on manmade habitats. Pol J Environ Stud 20:623-631

Zak JC, Willig MR, Moorhead DL, Wildman HG (1994) Functional diversity of microbial communities: a quantitative approach. Soil Biol Biochem 26:1101-1108

Zarzycki K, Trzcińska-Tacik H, Rożański W, Szeląg Z, Wołek J, Korzeniak U (2002) Ekologiczne liczby wskaźnikowe roślin naczyniowych Polski. Szafer Institute of Botany. Polish Academy of Science, Kraków (in Polish)

Zhang Ch, Ke S, Wang J, Ge Y, Chang SX, Zhu S, Chang J (2011) Responses of microbial activity and community metabolic profiles to plant functional group diversity in a full-scale constructed wetland. Geoderma 160:503-508 